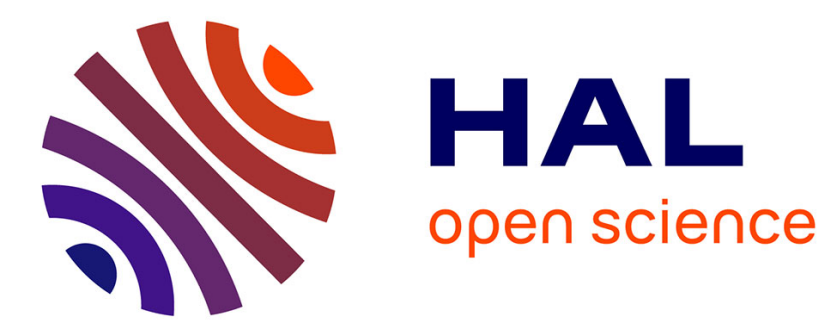

\title{
LASER CLADDING WITH COBALT-BASED HARDFACING ALLOYS
}

\author{
A. Frenk, J.-D. Wagnière
}

\section{To cite this version:}

A. Frenk, J.-D. Wagnière. LASER CLADDING WITH COBALT-BASED HARDFACING ALLOYS. Journal de Physique IV Proceedings, 1991, 01 (C7), pp.C7-65-C7-68. 10.1051/jp4:1991714 . jpa00250813

\section{HAL Id: jpa-00250813 https://hal.science/jpa-00250813}

Submitted on 1 Jan 1991

HAL is a multi-disciplinary open access archive for the deposit and dissemination of scientific research documents, whether they are published or not. The documents may come from teaching and research institutions in France or abroad, or from public or private research centers.
L'archive ouverte pluridisciplinaire HAL, est destinée au dépôt et à la diffusion de documents scientifiques de niveau recherche, publiés ou non, émanant des établissements d'enseignement et de recherche français ou étrangers, des laboratoires publics ou privés. 


\title{
LASER CLADDING WITH COBALT-BASED HARDFACING ALLOYS
}

\author{
A. FRENK and J.-D. WAGNIÈRE \\ Centre de Traitement des Matériaux par Laser, Ecole Polytechnique Fédérale de Lausanne, \\ CH-1015 Lausanne, Switzerland
}

\begin{abstract}
Preliminary results aimed at designing Co-based hardfacing alloys specifically for the laser cladding process are reported. Three alloys, ranging from hypo- to hypereutectic were deposited using scanning velocities between 1.7 and $170 \mathrm{~mm} / \mathrm{s}$. The microstructures and the dry sliding wear resistances of the clads were investigated. First trends relating composition to dry sliding wear resistance were deduced.
\end{abstract}

\section{Introduction}

The blown powder technique /1/ allows clads to be produced with a metallurgical bond and a low level of dilution. The rapid solidification rates associated with laser surface treatments produce very fine microstructures and can lead to transitions between growth morphologies $/ 2 /$, to extended solubilities and/or to the appearance of metastable phases. As the properties of an alloy are strongly dependant upon the microstructure, it is necessary to study the relationships between composition, solidification speed, microstructure and properties, in order to optimise the composition and processing conditions for a given application.

Cobalt based, Stellite-type alloys are widely used in industry due to their excellent combination of wear and corrosion properties $/ 3 /$. They usually contain two phases, a ductile cobalt-chromium phase and carbides of the $\mathrm{M}_{7} \mathrm{C}_{3}$ type. They can be classified as being hypoeutectic, eutectic or hypereutectic, with respect to the analogous pseudobinary system $(\mathrm{Co}, \mathrm{Cr})-\mathrm{Cr}_{7-\mathrm{x}} \mathrm{Co}_{\mathrm{x}} \mathrm{C}_{3} / 4 /$. This paper presents preliminary results aimed at designing Co-based hardfacing alloys specifically for the laser cladding process.

\section{Experiments}

Three commercially available Co-based alloys, ranging from hypoeutectic (Stellite 6) to highly hypereutectic (E16019)1, were deposited onto stainless steel substrates (DIN X2CrNiMo1814) using a $1.5 \mathrm{~kW} \mathrm{CO}$ laser. The chemical composition of the powders is given in Table 1, as well as their relative carbide fraction, determined using the chemical extraction technique described in $/ 5 /$. Table 2 gives the

${ }^{1}$ E16001 and E16019 stand for Eutroloy 16001 and Eutroloy 160019 respectively 
processing conditions used to produce the clads. The scanning velocities cover the whole range in which clads can be practically produced.

Table 1 : Chemical composition of the powders, in [wt\%]

\begin{tabular}{|c|cccccccccc|c|}
\hline Alloy & Co & Cr & C & W & Mn & B & Ni & Fe & A I & S i & Carb.fraction \\
\hline Stellite6 & Bal. & 28.0 & 1.10 & 4.54 & 0.09 & - & 0.04 & 0.5 & 1.28 & - & 9.3 \\
E16001 & Bal. & 29.0 & 2.7 & 12.6 & 0.1 & - & 0.9 & 0.9 & - & 1.2 & 28.7 \\
E16019 & Bal. & 26.3 & 3.4 & 13.1 & 0.1 & 0.6 & 1.4 & 0.9 & - & 1.2 & 40.5 \\
\hline
\end{tabular}

Table 2 : Laser processing conditions

\begin{tabular}{|l|c|c|c|}
\hline Processing condition & Slow & Intermediate & Fast \\
\hline Laser power [W] & 1500 & 1500 & 1500 \\
Beam diameter [mm] & 4 & 2 & 1 \\
Intertrack adv. [mm] & 1.2 & 0.6 & 0.1 \\
Scanning speed [mm/s] & 1.7 & 13.3 & 166.7 \\
Powder feed rate [g/s] & 0.03 & 0.1 & 0.2 \\
Coverage rate [mm2/s] & 2 & 8 & 17 \\
Clad thickness[mm] & 0.8 & 0.6 & 0.2 \\
\hline
\end{tabular}

The microstructures were examined using optical and scanning electron microscopy and the phases were determined using $\mathrm{X}$-ray analysis. Dry sliding wear experiments were carried out, using a pin-on-disc type machine. Pins $8 \mathrm{~mm}$ in diameter were spark eroded from the cladded samples. The discs were made from sintered WC-Co 90/10. Experiments were conducted using loads ranging from 50 to $800 \mathrm{~N}$ and sliding velocities from 0.5 to $10 \mathrm{~m} / \mathrm{s}$.

\section{Results and discussion}

The structures obtained in the three alloys deposited using the slow and fast processing speed are shown in transverse micrographs, Figures 1 to 3 . Note that there is a factor of 10 difference between the magnifications of the slow and fast processing conditions. The structure of the hypoeutectic alloy, Stellite 6 , consists of primary $(\mathrm{Co}, \mathrm{Cr})$ dendrites surrounded by a fine eutectic containing $\mathrm{M}_{7} \mathrm{C}_{3}$ carbides. A marked decrease in the size of the microstructure with the increase in processing speed can be seen. A mean value for the secondary dendrite arm spacing, $\lambda_{2}$, decreasing from 4.2 to 1.3 and down to $0.9 \mu \mathrm{m}$ has been measured for the three scanning speeds investigated. For the alloy E16001, a slow processing condition produces a hypereutectic structure in the overlapping areas (where the solidification speed is at the lowest, center part of the Figure), with primary $\mathrm{M}_{7} \mathrm{C}_{3}$ carbides surrounded by eutectic. However, the structure becomes purely eutectic as the solidification speed increases. The intermediate and fast processing speed leads to a very fine eutectic structure (with an interlamellar spacing $\lambda$ of about 100 and $50 \mathrm{~nm}$ respectively). In the overlapping zones, a thermal coarsening of the structure seems to have occured. The microstructure of the hypereutectic alloy E16019 is shown in Figure 3. With the low processing speed the structure contains big primary needle-like $\mathrm{M}_{7} \mathrm{C}_{3}$ carbides surrounded by eutectic. With the fast processing condition, one can still observe big primary carbides in the overlapping areas (lower left corner), but with an increase in the solidification speed, these rapidly transform to primary dendritic carbides before the structure becomes entirely eutectic. The main differences between the deposits are the carbide fraction, clearly related to the carbon content, and the morphology of the phases, which is strongly affected by the processing condition. 

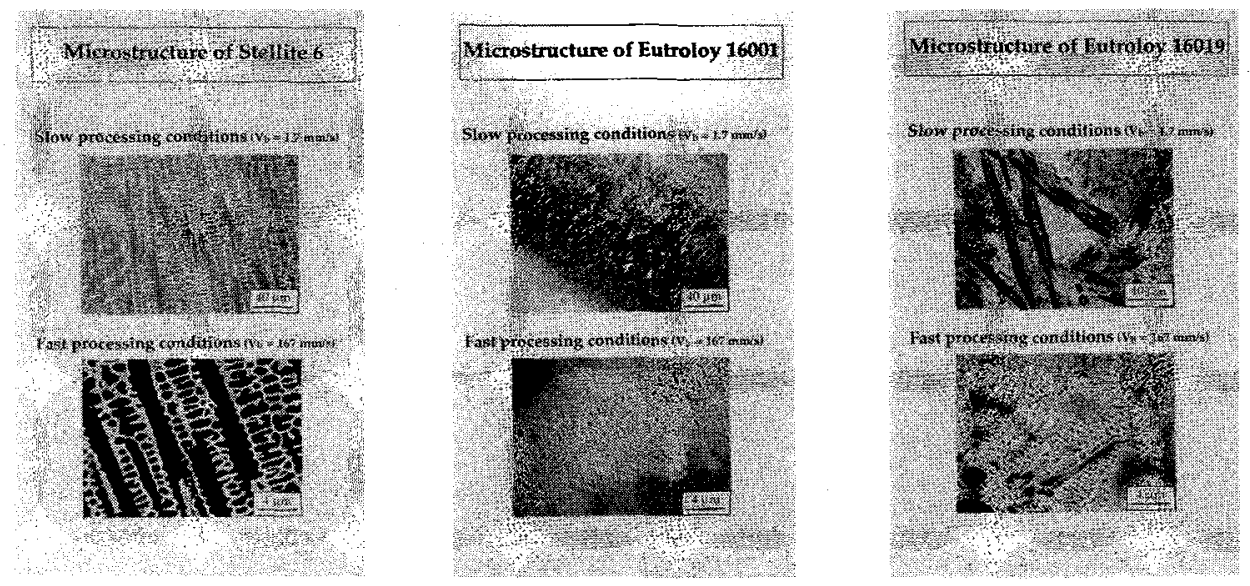

Figures 1 to 3 : Microstructures of the alloys deposited using the slow and fast processing condition

However, the carbide fraction is also influenced by the solidification speed. Two effects are known to affect the microsegregation, and therefore the second phase (here the carbide) content in hypoeutectic alloys. Firstly an increase in the dendrite tip concentration with the solidification speed, and secondly, the modification of the partition coefficient due to loss of local thermodynamic equilibrium at the growing interface $/ 6 /$. A determination of the carbide fraction in the hypoeutectic deposits was carried out $/ 7 /$ and related to the solidification speed estimated using a numerical model $/ 8 /$. Figure 4 shows that the carbide fraction decreases by approximately $10 \%$ between the slow and fast processing condition.

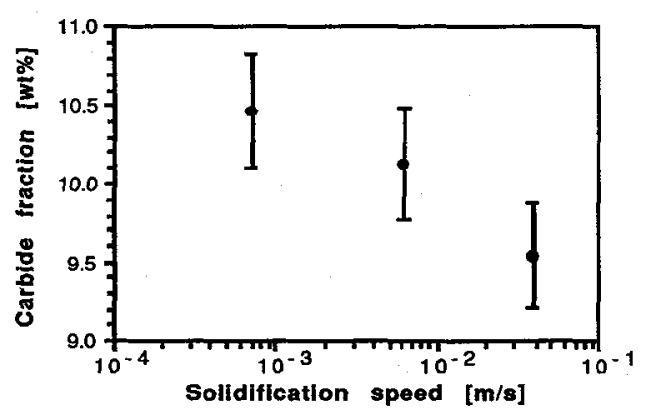

Figure 4 : Influence of the solidification speed on the carbide fraction in Stellite 6 deposits

Wear experiments were carried out on the clads produced using the intermediate processing condition (i.e. $13.3 \mathrm{~mm} / \mathrm{s}$ ). The results obtained for the three alloys were plotted in the form of wear maps $/ 9 /$. These maps are shown in Figures 5 to 7 . Each point in the XY plane represents a given set of experimental conditions (sliding velocity and applied load), and the corresponding wear rate is given in the $\mathrm{Z}$ axis.

In general, the measured wear rates were seen to decrease as the carbide content of the alloy increased. For the three alloys, a more or less regular increase in the wear rate with the load was observed. For the hypoeutectic alloy (Stellite 6), the wear rate passes through a maximum with the sliding velocity under a given load. Using a load of $50 \mathrm{~N}$, observation of the wear debris and worn surfaces indicated that the increase in the wear rate with the sliding velocity could be attributed to a transition from an oxidative to 
a metallic wear regime. For the eutectic alloy, E16001, the sliding velocity has little effect on the wear rate under low loads $(50 \mathrm{~N})$. However, under high loads $(800 \mathrm{~N})$, the wear rate passes again through a maximum. The highly hypereutectic alloy, E16019, exhibits a much flatter map, with a variation in the sliding velocity having little effect on the wear rate. Investigations are currently being carried out to elucidate the wear mechanisms involved in the eutectic and hypereutectic alloy.
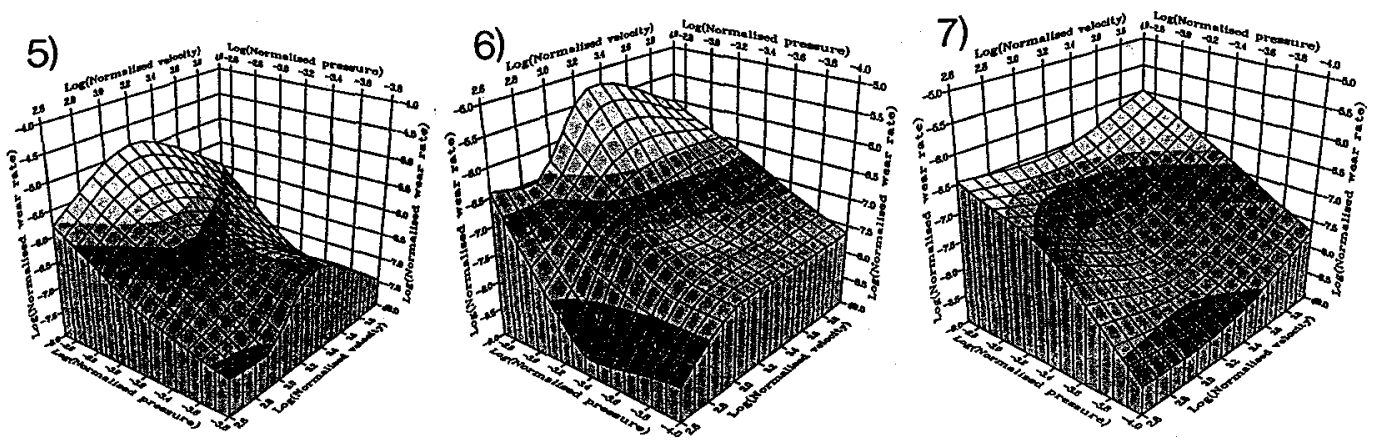

Figure 5 to 7 : Dry sliding wear maps for Stellite 6, E16001 and E16019 respectively

\section{Conclusions}

The microstructures obtained with different Cobalt-based hardfacing alloys, deposited with a $\mathrm{CO}_{2}$ laser under extreme processing conditions were investigated. Important variations in both the size and morphology of the carbides phases were observed. The dry sliding wear rates of these alloys deposited using intermediate processing speed were determined over a large range of applied loads and sliding velocities. The highly hypereutectic alloy was observed to be the most wear resistant. Future work will concentrate on determining the influence of the processing speed on the wear rate, which will help in the development of new alloys designed specifically for laser cladding.

\section{Acknowledgements}

The authors would like to thank the "Commission pour l'Encouragement de la Recherche Scientifique", Bern, as well as "Sulzer Innotec", Winterthur, for financial support.

\section{References}

/1/ V.M. Weerasinghe, W.M. Steen, Proc. Conf. Lasers in Materials Processing, M.M. Chen et al. ed., ASME, New York, 1983, 15

12/ W. Kurz, D.J. Fisher, Int. Metals Reviews, 5/6, 1979, 177

/3/ K.C. Antony, J. of Metals, 1983, 52

/4/ P.R. Sahm, M. Lorenz, W. Hugi, V. Frühauf, Metall. Trans., 3, 1972, 1022

15/ W.L. Silence, Wear of Materials, 1977, 77

/6/ W. Kurz, D.J. Fisher, Fundamentals of solidification, Trans Tech Publications, Aedermannsdorf, Switzerland, 3rd ed., 1989

$7 / \mathrm{N}$. Henchoz, Influence de la vitesse de solidification sur la fraction de carbures dans des recouvrements par laser, Travail pratique de diplôme EPFL, Lausanne, Switzerland, 1991

/8/ A.F.A Hoadley, C.F. Marsden, M. Rappaz, Proc. Conf. 22nd ICHMT on Manufacturing and Materials Processing, Dubrovnik 1990, Hemisphere, New York, 1991

19/ S.C. Lim, M.F. Ashby, Acta Metall., 35, 1, 1987, 1 